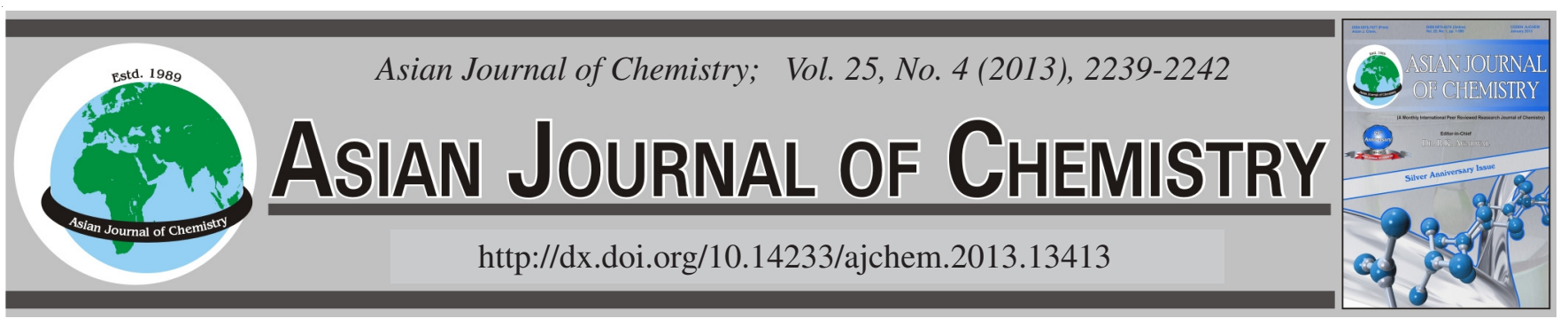

\title{
Synthesis, Spectral Characterization and Biological Evaluation of Schiff Base Transition Metal Complexes Derived from Ampicillin with D-Glucose
}

\author{
NArjis Naz ${ }^{1, *}$, Shakera Khatoon ${ }^{2}$, Humayun Ajaz $^{3}, Z_{\text {Udi }}$ SAdiQ $^{1}$ and Muhammad Zafar IqbaL ${ }^{1}$
}

${ }^{1}$ Department of Chemistry, Lahore College for Women University, Lahore-54000, Pakistan

${ }^{2}$ Gujranwala Institute of Nuclear Medicine and Radiotherap, Gujranwala, Pakistan

${ }^{3}$ Department of Chemistry, University of Engineering \& Technology, Lahore-54000, Pakistan

*Corresponding author: E-mail: narjis107@gmail.com

(Received: 9 January 2012;

Accepted: 19 October 2012)

AJC-12320

Schiff base metal complexes derived from ampicillin with $\mathrm{D}$-glucose and $\mathrm{Mn}(\mathrm{II}), \mathrm{Fe}(\mathrm{II}), \mathrm{Co}(\mathrm{II}), \mathrm{Ni}(\mathrm{II}), \mathrm{Cu}(\mathrm{II})$ and $\mathrm{Zn}(\mathrm{II}) \mathrm{have}$ been
successfully synthesized. Elemental analysis, molar conductance, magnetic susceptibility, thermal analysis along with electronic and
infrared spectral studies determined the structural assessment of complexes that formulated as $\mathrm{ML}_{2}$ type. All the compounds under
investigation were screened for antimicrobial appraisal to evaluate the effect of derivatization and metals on antibiotic. It evidenced that
all the schiff base metal complexes are more potential bactericidal agents as compared to parent ampicillin.
Key Words: Ampicillin, Coordination complexes, Biological assay, D-Glucose, Schiff base complexes.

\section{INTRODUCTION}

Ampicillin, belonging to $\beta$-lactam antibiotics, is an influential antibacterial means in pharmaceutical products. Derivatization and adulteration of curing agents is a need of time due to rapidly emerging antimicrobial resistance ${ }^{1-3}$. Researchers pay their attention in seeking miscellaneous approaches and novel competent molecules that best endure with such crisis and widen the range of $\operatorname{drugs}^{4-6}$. Therapeutic applications of Schiff bases like antibacterial, antifungal, antiinflammatory, antipyretic, antitumor etc., have been profoundly studied $^{7-9}$ and their role as complexing agent is appreciative $^{10}$ that put up metal based therapy. Literature review exposed that some antibiotics show significantly improved results when chelated with different metal ions rather than as simple biological molecule ${ }^{11,12}$ and their chelated tendency can be increased by condensing it with carbonyl compounds ${ }^{13,14}$. The presence of $-\mathrm{C}=\mathrm{N}-, \mathrm{S}$ and $\mathrm{O}$ contributors in chelating ligands concluded excellent biological ${ }^{15,16}$ evaluation that prompted us to present this piece of writing as a progress of our research. Bacillus subtilis, Escherichia coli, Pseudomonas aeruginosa and Staphylococcus aureus strains were examined for antimicrobial testing.

\section{EXPERIMENTAL}

All the chemical reagents and solvents employed for the syntheses were of AR grade and obtained from E. Merck and
Sigma Chemicals Company. Ampicillin in its pure form was obtained form Remington Pharmaceutical Corporation Pvt. Ltd. and was used with no additional purification. Decomposition points of the complexes were taken on Gallenkamp melting point device. Molar conductance of Schiff base transition metal complexes was determined in DMSO at normal laboratory temperature by using Wescan-212 conductivity meter. Magnetic moments of the solid complexes under investigation were determined at room temperature by the Gouy's technique using mercury(II) tetrathiocyanatocobaltate as the caliberant. Microanalysis for carbon, hydrogen and nitrogen was carried out with Carlo Erba-1106 micro analyzer. The metal contents in selected compounds were determined by atomic absorption spectrophotometer model A-A 1275. The electronic absorption spectra were recorded on Hitachi 220S (UV-VIS) spectrophotometer in DMF in 220-900 nm regions. The FTIR spectra were recorded using Michaelson Bomen series spectrophotometer, using $\mathrm{KBr}$ disc technique.

Synthesis of Schiff base ligand: An equimolar mixture of ampicillin $(0.349 \mathrm{~g})$ in $50 \mathrm{~mL}$ of methanol and D-glucose $(0.180 \mathrm{~g})$ in $50 \mathrm{~mL}$ of methanol was well dissolved. To this homogenous mixture, $\mathrm{KOH}(0.1 \%$ in methanol) was added and refluxed about $0.5 \mathrm{~h}$. Yellow coloration in reaction pot indicated the synthesis of Schiff base ligand (Scheme-I).

Preparation of metal complexes: The coloured solution obtained above was mixed with the solution of $\mathrm{MnCl}_{2} \cdot 4 \mathrm{H}_{2} \mathrm{O}$ (4 mmol, $0.792 \mathrm{~g}$ ) in methanol and refluxed. The refluxing 


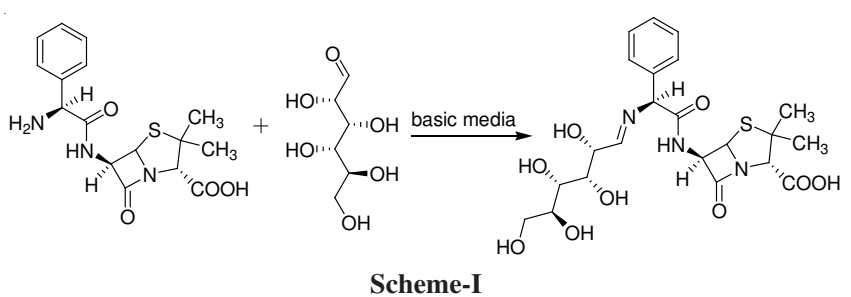

was continued for about $2 \mathrm{~h}$. The pink solid was filtered off and washed with distilled water then ethanol and finally with methanol. It was dried in vacuum over $\mathrm{CaCl}_{2}$ to get complex 1 in $54 \%$ yield. The $\mathrm{FeSO}_{4} \cdot 2 \mathrm{H}_{2} \mathrm{O}$ solution ( $4 \mathrm{mmol}, 0.748 \mathrm{~g}$ ) produced reddish brown colour product as compound 2 in 42 $\%$ yield while the dark brown precipitates in $68 \%$ yield were obtained when $4 \mathrm{mmol} \mathrm{CoCl}_{2} \cdot 6 \mathrm{H}_{2} \mathrm{O}(0.948 \mathrm{~g})$ solution was used (complex 3). The solution of $\mathrm{NiCl}_{2} \cdot 6 \mathrm{H}_{2} \mathrm{O}$ (4 mmol, 0.951 g) furnished complex 4 as light green cake in $54 \%$ yield. Complex 5 as light brown precipitates (58\% yield) was achieved by taking $4 \mathrm{mmol}(0.796 \mathrm{~g})$ of $\mathrm{Cu}(\mathrm{OAc})_{2} \cdot \mathrm{H}_{2} \mathrm{O}$ solution. The $\mathrm{Zn}(\mathrm{OAc})_{2} \cdot \mathrm{H}_{2} \mathrm{O}(4 \mathrm{mmol}, 0.806 \mathrm{~g})$ solution furnished complex 6 as dirty white appearance in $52 \%$ yield (Scheme-II).

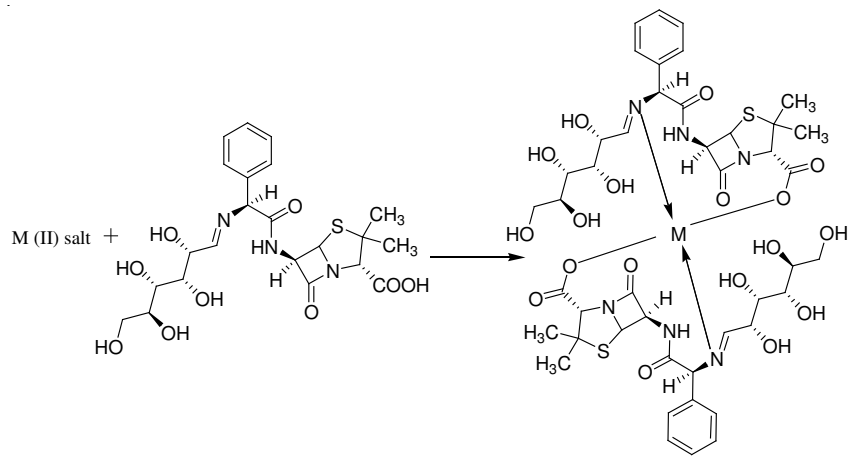

Scheme-II

All the unique complexes were confirmed by elemental and spectral analysis.

Antimicrobial screening: The in vitro biological activities of all three Schiff base transition metal complexes derived from ampicillin, glucose (a dextrose sugar) and $\mathrm{Mn}$ (II), $\mathrm{Fe}(\mathrm{II}) \mathrm{Co}(\mathrm{II})$, $\mathrm{Ni}(\mathrm{II}), \mathrm{Cu}(\mathrm{II})$ and $\mathrm{Zn}$ (II) metal ions were investigated by agar diffusion disc method. For these purpose clinically important gram positive pathogenic bacterial strains like Bacillus subtilis and Staphylococcus aureus and gram negative infectious bacterial species like Escherichia coli and Pseudomonas aeruginosa were selected. The antimicrobial activities of each of these complexes were compared with pure ampicillin. The tested concentration of compounds was $10 \mu \mathrm{g} / 10 \mu \mathrm{L}$ in DMSO solvent. The susceptibility zones after incubation were recorded in mm carefully.

\section{RESULTS AND DISCUSSION}

Physicochemical properties of complexes 1-6: This work deals with the investigation of complexes prepared through Schiff base ligand and manganese, iron, cobalt, nickel, copper and zinc hydrated salts in methanol independently. An amino functionality in ampicillin antibiotic was accessible to react at aldehydic centre of glucose to achieve Schiff base. This alcoholic solution of schiff base was directly reacted with excess of metal salt in methanol to furnish complexes. Finally the complexes were filtered off, washed with organic solvents, dried and save in desiccator till further utilization. The newly synthesized schiff base metal complexes were solid and very stable at laboratory temperature. These were soluble in DMF and DMSO solvents.

The ligand can not be isolated under normal conditions due to its instability. It is well documented that Schiff bases usually isolated as metal complexes because they rapidly hydrolyzed ${ }^{17}$ when derived from aliphatic carbonyl moieties. In our experiments, solution colour alteration revealed the formation of chelating ligand. The presence of colour along with absorption at $390-400 \mathrm{~nm}$ in UV-visible spectrum is a characteristic feature of azomethine group $(-\mathrm{CH}=\mathrm{N}-)^{18}$. These compounds did not possess sharp melting points but decomposed when heated above $200{ }^{\circ} \mathrm{C}$. The complexes 1-6 were non-electrolytes as shown by their molar conductivity in DMSO at room temperature ${ }^{19}$, in the range of 3.86-4.26 $\Omega^{-1}$ $\mathrm{cm}^{2} \mathrm{~mol}^{-1}$ (Table-1).

The elemental analysis of the synthesized compounds (Table-1) enlightened that the complexes have metal:ligand anion stoichiometry of $1: 2$ equivalent to $\mathrm{ML}_{2}$ composition where $\mathrm{L}$ is the Schiff base ligand and $\mathrm{M}$ is the metal ion. The analytical data are in fine harmony with the anticipated stoichiometry of the complexes. Moreover atomic absorption

TABLE-1

ANALYTICAL AND PHYSICAL CHARACTERISTICS OF SYNTHESIZED COMPOUNDS 1-6

\begin{tabular}{|c|c|c|c|c|c|c|c|c|}
\hline \multirow{2}{*}{ Complex } & \multirow{2}{*}{ m.f./ (m.w.) } & \multirow{2}{*}{$\mu_{\text {eff }} \mathrm{BM}$} & \multirow{2}{*}{$\lambda_{\mathrm{M}}$} & \multirow{2}{*}{$\lambda_{\max }(\mathrm{nm})$} & \multicolumn{4}{|c|}{ Elemental analysis \% (theoretical) } \\
\hline & & & & & M & $\mathrm{C}$ & $\mathrm{H}$ & $\mathrm{N}$ \\
\hline 1 & $\begin{array}{c}\left(\mathrm{C}_{22} \mathrm{H}_{28} \mathrm{~N}_{3} \mathrm{O}_{9} \mathrm{~S}\right)_{2} \mathrm{Mn} \\
(1075)\end{array}$ & 5.86 & 4.26 & 281 (40016), 335 (6997), 406(12) & $\begin{array}{c}4.9 \\
(5.10)\end{array}$ & $\begin{array}{c}48.92 \\
(49.09)\end{array}$ & $\begin{array}{c}5.18 \\
(5.24)\end{array}$ & $\begin{array}{c}7.62 \\
(7.81)\end{array}$ \\
\hline 2 & $\begin{array}{c}\left(\mathrm{C}_{22} \mathrm{H}_{28} \mathrm{~N}_{3} \mathrm{O}_{9} \mathrm{~S}\right)_{2} \mathrm{Fe} \\
(1075)\end{array}$ & 5.23 & 3.99 & 286 (40030), 332 (7030) & $\begin{array}{c}4.89 \\
(5.18)\end{array}$ & $\begin{array}{c}48.98 \\
(49.05)\end{array}$ & $\begin{array}{c}5.20 \\
(5.24)\end{array}$ & $\begin{array}{c}7.74 \\
(7.80)\end{array}$ \\
\hline 3 & $\begin{array}{c}\left(\mathrm{C}_{22} \mathrm{H}_{28} \mathrm{~N}_{3} \mathrm{O} \mathrm{O}_{9} \mathrm{~S}\right)_{2} \mathrm{Co} \\
(1079)\end{array}$ & 2.78 & 4.18 & 290 (40010), 332(7001) & $\begin{array}{c}5.38 \\
(5.45)\end{array}$ & $\begin{array}{c}48.76 \\
(48.91)\end{array}$ & $\begin{array}{c}5.16 \\
(5.22)\end{array}$ & $\begin{array}{c}7.69 \\
(7.78)\end{array}$ \\
\hline 4 & $\begin{array}{c}\left(\mathrm{C}_{22} \mathrm{H}_{28} \mathrm{~N}_{3} \mathrm{O}_{9} \mathrm{~S}\right)_{2} \mathrm{Ni} \\
(1078.7)\end{array}$ & - & 3.86 & 282 (40022), 329 (7015), 498 (72) & $\begin{array}{c}5.36 \\
(5.44)\end{array}$ & $\begin{array}{c}48.88 \\
(48.92)\end{array}$ & $\begin{array}{l}5.13 \\
(5.23)\end{array}$ & $\begin{array}{c}7.71 \\
(7.78)\end{array}$ \\
\hline 5 & $\begin{array}{c}\left(\mathrm{C}_{22} \mathrm{H}_{28} \mathrm{~N}_{3} \mathrm{O}_{9} \mathrm{~S}\right)_{2} \mathrm{Cu} \\
(1083.5)\end{array}$ & 1.96 & 3.95 & 278 (40010), 326 (7076), 684 (485) & $\begin{array}{l}5.76 \\
(5.86)\end{array}$ & $\begin{array}{c}48.65 \\
(48.70)\end{array}$ & $\begin{array}{c}5.12 \\
(5.20)\end{array}$ & $\begin{array}{c}7.66 \\
(7.74)\end{array}$ \\
\hline 6 & $\begin{array}{c}\left(\mathrm{C}_{22} \mathrm{H}_{28} \mathrm{~N}_{3} \mathrm{O} \mathrm{O}_{9} \mathrm{~S}\right)_{2} \mathrm{Zn} \\
(1085.4)\end{array}$ & - & 4.18 & 283 (40021), 332 (70002) & $\begin{array}{c}5.93 \\
(6.02)\end{array}$ & $\begin{array}{c}48.57 \\
(48.62)\end{array}$ & $\begin{array}{c}5.09 \\
(5.19)\end{array}$ & $\begin{array}{c}7.59 \\
(7.73)\end{array}$ \\
\hline
\end{tabular}

$\lambda_{\mathrm{M}}=$ conductivity $\left(\Omega^{-1} \mathrm{~cm}^{2} \mathrm{~mol}^{-1}\right), \mathrm{M}=$ metal. 
spectroscopy determined the amount of metal in 1-6 that also corroborated the ligand to metal ratio as $2: 1$. Theoretical and experimental percentage of metals ( $\mathrm{Mn}, \mathrm{Fe}, \mathrm{Co}, \mathrm{Ni}, \mathrm{Cu}, \mathrm{Zn}$ ) in such complexes is tabulated. Thermal assessment of these complexes depicted the absence of coordinated or lattice water ${ }^{20}$ as there was no weight loss when heated between 100$180{ }^{\circ} \mathrm{C}$ and show mainly one step in the decomposition progression over temperature ranges from $220-638^{\circ} \mathrm{C}$ with the mass loss of 93.12-92.34\% (calculated 93.41-92.51\%). The remaining weight 7.18-6.45\% (calculated 7.49-6.59\%) corresponds to respective metal oxides ${ }^{21}$.

\section{Infrared spectral analysis of complexes 1-6}

The IR data of all the complexes are specified as: Pure ampicillin: 3210s [ $\mathrm{NH}$ (amide)], 2716w,b $\left(\mathrm{NH}_{3}{ }^{+}\right), 1770 \mathrm{~s}[\mathrm{C}=\mathrm{O}$ ( $\beta$ lactam)], 1690s [C=O (amide)], 1610s (COO, asym), 1458s (COO, sym), 1072s (CN), 600w (CS); Complex 1: 3276s [NH (amide)], 1772s [C=O ( $\beta$ lactam)], 1692s [C=O (amide)], 1652s (COO, asym), 1598s (C=N), 1422s (COO, sym), 1072s $(\mathrm{CN}), 602 \mathrm{w}(\mathrm{CS}), 565 \mathrm{~m}(\mathrm{M}-\mathrm{N}), 469 \mathrm{~m}(\mathrm{M}-\mathrm{O})$; complex 2: 3278s [NH (amide)], 1772s [C=O ( $\beta$ lactam)], 1692s [C=O (amide)], 1652s (COO, asym), 1600s $(\mathrm{C}=\mathrm{N}), 1424 \mathrm{~s}(\mathrm{COO}$, sym), 1074s (CN), 602w (CS), 562m (M-N), 460m (M-O); Complex 3: 3273s [NH (amide)], 1770s [C=O ( $\beta$ lactam)], 1688s $[\mathrm{C}=\mathrm{O}$ (amide)], 1656s $(\mathrm{COO}$, asym), 1600s $(\mathrm{C}=\mathrm{N})$, 1424s (COO, sym), 1074s (CN), 602w (CS), 562m (M-N), 468m (M-O); Complex 4: 3276s [NH (amide)], 1772s [C=O ( $\beta$ lactam) $), 1688 \mathrm{~s}$ [C=O (amide)], 1656s (COO, asym), 1600s $(\mathrm{C}=\mathrm{N}), 1425 \mathrm{~s}$ (COO, sym), 1070s (CN), 604w (CS), 565m (M-N), 469m (M-O); Complex 5: 3276s [NH (amide)], 1774s $[\mathrm{C}=\mathrm{O}(\beta$ lactam $)], 1688 \mathrm{~s}[\mathrm{C}=\mathrm{O}$ (amide), $1654 \mathrm{~s}(\mathrm{COO}$, asym), 1598s $(\mathrm{C}=\mathrm{N}), 1425 \mathrm{~s}(\mathrm{COO}, \mathrm{sym}), 1072 \mathrm{~s}(\mathrm{CN}), 604 \mathrm{w}(\mathrm{CS})$, 565m (M-N), 468m (M-O); complex 6: 3278s [NH (amide)], 1772s $[\mathrm{C}=\mathrm{O}(\beta$ lactam $)], 1688 \mathrm{~s}[\mathrm{C}=\mathrm{O}$ (amide) $], 1656 \mathrm{~s}(\mathrm{COO}$, asym), 1598s (C=N), 1424s (COO, sym), 1072s (CN), 602w (CS), 564m (M-N), 469m (M-O).

The FTIR spectrum of pure ampicillin shows stretching vibration at $3210 \mathrm{~cm}^{-1}$ due to amino group and absorption band at $1774-1770 \mathrm{~cm}^{-1}$ is assigned to $\beta$-lactam $v(\mathrm{C}=\mathrm{O})$ stretching mode ${ }^{22,23}$. Absence of band at 3210 and $2840 \mathrm{~cm}^{-1}$ due to free carbonyl group present in D-glucose in all the complexes 1-6 indicated the condensation of $\mathrm{NH}_{2}$ moiety of ampicillin and aldehydic $\mathrm{CO}$ of glucose to formulate $-\mathrm{CH}=\mathrm{N}$ - functionality.

An absorption band at $1600-1598 \mathrm{~cm}^{-1}$ is assigned to the presence of azomethine (- $\mathrm{CH}=\mathrm{N}-)$ group coordinated to metal ions in the complexes. The characteristic IR band in Schiff bases for $-\mathrm{CH}=\mathrm{N}$ - functionality was observed in 1650-1630 $\mathrm{cm}^{-1}$ in literature ${ }^{24,25}$. The decrease in frequency for this group was observed in all the complexes that assigned the involvement of azomethine nitrogen in coordination ${ }^{26,27}$. The spectra of all the investigated complexes showed strong absorption bands at $1774-1770 \mathrm{~cm}^{-1}$ is assigned to $\beta$-lactam $v(\mathrm{C}=\mathrm{O})$ stretching mode present in antibiotic. The presence of absorption band at this region also ruled out the utilization of $\beta$-lactam $\nu(\mathrm{C}=\mathrm{O})$ in the coordination. Both $v(\mathrm{C}-\mathrm{S})$ and $v(\mathrm{C}-\mathrm{N})$ were almost unaffected relatively to the absorption bands of pure ampicillin $^{22,23}$ and also ruled out the involvement these groups in coordination. Free carboxylate (COO) in uncomplexed ampi- cillin shows absorption band at 1610 and $1485 \mathrm{~cm}^{-1}$ region for asymmetric and symmetric vibrations ${ }^{22,23}$. In all the complexes the carboxylate $\mathrm{v}(\mathrm{COO})_{\text {sym }}$ were shifted towards lower wave numbers at $1424-1422 \mathrm{~cm}^{-1}$ while $v(\mathrm{COO})_{\text {asy }}$ were shifted towards higher wave numbers at $1656-1652 \mathrm{~cm}^{-1}$. This investigational judgment clearly indicates that carboxylate is involved in coordination in all complexes. The $\Delta v$ value $\left[\Delta v=v(C O O)_{\text {sym }}\right.$ $\left.-v(C O O)_{\text {asy }}\right]$ is equal to 151 for pure ampicillin. The $\Delta v$ values in all the complexes increased by $232-228 \mathrm{~cm}^{-1}$ which are characteristic of monodentate carboxylate ion in coordination with metal ${ }^{28}$. In the spectra of complexes, new bands observed in 565-562 and 469-460 $\mathrm{cm}^{-1}$ regions can be said due to $v(\mathrm{M}-\mathrm{N})$ and $v(\mathrm{M}-\mathrm{O})$, respectively ${ }^{29,30}$. This substantiates the chelation of metal ions through nitrogen and oxygen in the ampicillin transition metal complexes.

Electronic spectral and magnetic moment studies: The electronic absorption spectra exhibit the significant information for the explanation of transitions present in complexes 1-6. The strong band around 278-290 nm reveals the existence of phenyl ring $\pi-\pi^{*}$ transition $^{31}$. Band display at $326-335 \mathrm{~nm}$ attributed to the $\pi-\pi^{*}$ transition originating in $-\mathrm{CH}=\mathrm{N}$ chromophor $^{31,32}$. Lower energy bands in the UV-visible spectra are assigned to the $d-d$ transition in the complexes. Magnetic moments of 1-6 were observed and listed in Table-1. Normal magnetic moment values of all the complexes pointed toward their mononuclear nature. Magnetic moment value of $\mathrm{Co}$ (II) complex is $2.83 \mathrm{BM}$ and posses square planar geometry ${ }^{33}$ while for $\mathrm{Ni}$ (II) complex is zero which indicates that complex has square planar structure ${ }^{34,35}$. For Fe(II) complex, it is 5.30 MB that may refer tetrahedral or octahedral shape. Planar geometry is expected for $\mathrm{Cu}$ (II) and $\mathrm{Zn}$ (II) complexes. As the $\mathrm{Mn}$ (II) and $\mathrm{Fe}$ (II) complex under investigation is four-coordinated, tetrahedral geometry is purposed for this ${ }^{34,35}$.

Biological screening: The antibacterial behaviour of all the synthesized Schiff base transition metal complexes were evaluated against Bacillus subtilis, Escherichia coli, Staphylococcus aureus and Pseudomonas aeruginosa. The extent of effectiveness was determined by measuring diameter of clear inhibitory zone caused by samples and reported in Table- 2 . All the six complexes demonstrated amplified bactericidal consequences when contrast with unadulterated ampicillin as indicated in Fig. 1. A cursory outlook of data displays the succeeding tendency in microbiological studies of drug metal complexes: $\mathrm{Co}$ (II) $>\mathrm{Ni}$ (II) $>\mathrm{Zn}$ (II) and $\mathrm{Fe}$ (II) $>\mathrm{Cu}$ (II) and $\mathrm{Mn}(\mathrm{II})>$ pure ampicillin.

TABLE-2

ANTIMICROBIAL ASSESSMENT STATISTICS OF STUDIED COMPLEXES

\begin{tabular}{|c|c|c|c|c|}
\hline \multirow[b]{2}{*}{ Ampicillin/complex } & \multicolumn{4}{|c|}{ In vitro inhibitory zone (mm) } \\
\hline & $\begin{array}{c}B . \\
\text { subtilis }\end{array}$ & $\begin{array}{c}E . \\
\text { coli }\end{array}$ & $\begin{array}{c}P . \\
\text { aeruginosa }\end{array}$ & $\begin{array}{c}S . \\
\text { aureus }\end{array}$ \\
\hline Ampicillin & ++ & ++ & ++ & ++ \\
\hline (Glu-ampi) ${ }_{2} \mathrm{Mn}$ & +++ & +++ & +++ & +++ \\
\hline (Glu-ampi) $)_{2} \mathrm{Fe}$ & +++ & +++ & +++ & +++ \\
\hline$(\text { Glu-ampi) })_{2} \mathrm{Co}$ & ++++ & ++++ & ++++ & ++++ \\
\hline (Glu-ampi ${ }_{2} \mathrm{Ni}$ & +++ & +++ & ++++ & +++ \\
\hline (Glu-ampi) ${ }_{2} \mathrm{Cu}$ & +++ & +++ & +++ & +++ \\
\hline (Glu-ampi) ${ }_{2} \mathrm{Zn}$ & +++ & +++ & +++ & +++ \\
\hline
\end{tabular}

Inhibition zone diameter mm: ++, 15-20; +++, 21-25; ++++, 26-30. 


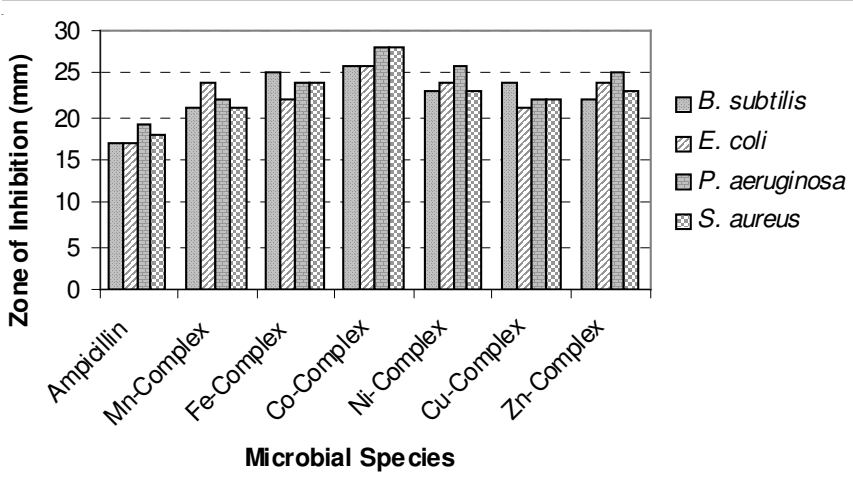

Fig. 1. Biological assay of metal complexes

\section{Conclusion}

Based on the results acquired from elemental and spectral analysis, all complexes reported in this work appear to be fourcoordinated. Coordinating groups, depicted by FTIR data, are $-\mathrm{C}=\mathrm{N}$ and $-\mathrm{COO}$ that are present in Schiff ligand. The unique molecular structures of newly synthesized complexes highlight pronounced antibacterial properties as compared to uncomplexed ampicillin thus introducing as new class of metalbased bactericides. Cobalt complex showed excellent inhibitory effects against growth of microorganism. Thus, derivatization of antibiotics with carbonyl compound and metal ions possesses immense potential as medicinal agents and offering an invigorating spot for research.

\section{ACKNOWLEDGEMENTS}

The authors are obliged to Dr. Erum Akbar Hussain and Kundian Chemical Plant I Pakistan for providing assistance in this research work.

\section{REFERENCES}

1. V. Klimesova, L. Zahajka, K. Waisser, J. Kaustova and U. Mollmann, Il Farmaco, 59, 279 (2004).

2. S. Tehranchian, T. Akbarzadeh, M.R. Fazeli, H. Jamalifar and A. Shafiee, Bioorg. Med. Chem. Lett., 15, 1023 (2005).

3. G.B. Bagihalli, P.G. Avaji, S.A. Patil and P.S. Badami, Eur. J. Med. Chem., 43, 2639 (2008).

4. N. Gumrukcuoglu, M. Serdar, E. Celik, A. Sevim and N. Demirbas, Turk. J. Chem., 31, 335 (2007).

5. J. Garcia-Lara, M. Masalha and S.J. Foster, Drug Discov. Today, 10, 643 (2005).
6. D. Becker, M. Selbach, C. Rollenhagen, M. Ballmaier, T.F. Meyer, M. Mann and D. Bumann, Nature, 440, 303 (2006).

7. K. Singh, M.S. Barwa and P. Tyagi, Eur. J. Med. Chem., 42, 394 (2007).

8. A.K. Halve, D. Bhadauria, B. Bhaskar, R. Dubey and V. Sharma, Indian J. Pharm. Sci., 69, 680 (2007).

9. S. Kumar, D.N. Dhar and P.N. Saxena, J. Sci. Ind. Res., 68, 181 (2009).

10. S. Baluja, A. Solanki and N. Kachhadia, J. Iran. Chem. Soc., 3, 312 (2006).

11. E. Canpolat and M. Kaya, Turk. J. Chem., 29, 409 (2005).

12. R. Ramesh and M. Sivagamasundari, Synth. React. Inorg. Met.-Org. Chem., 33, 899 (2003).

13. M.S. Iqbal, I.H. Bukhari and M. Arif, Appl. Organomet. Chem., 19, 864 (2005).

14. N. Raman, Y.P. Raja and A. Kulandaisamy, Proc. Indian Acad. Sci. (Chem. Sci.), 113, 183 (2001)

15. Z.H. Chohan, C.T. Supuran and A. Scozzafava, J. Enzyme Inhib. Med. Chem., 19, 79 (2004).

16. N. Raman, A. Kulandaisamy, C. Thangaraja and K. Jeyasubramanian, Transition Met. Chem., 28, 29 (2003).

17. M.S. Iqbal, S.J. Khurshid and M.Z. Iqbal, J. Pak. Med. Assoc., 40, 221 (1990).

18. M.S. Iqbal, S.J. Khurshid and M.Z. Iqbal, Can. J. Chem., 71, 629 (1993).

19. N. Raman and S. Ravichandran, Polish J. Chem., 78, 2005 (2004).

20. R.K. Agarwal, L. Singh, D.K. Sharma and R. Singh, Turk. J. Chem., 29, 309 (2005).

21. E. Canpolat and M. Kaya, Russian J. Chem., 31, 415 (2005).

22. P.K. Bhattacharrya and W.M. Cort, Anal. Profiles Drug Substances, 7, 28 (1978).

23. E. Ivashikiv, Anal. Profiles Drug Substances, 2, 5 (1973).

24. K. Nakamoto, Infrared and Raman Spectra of Inorganic and Coordination Compounds, Wiley, New York, Part B, edn. 5, p. 59 (1997).

25. J.R. Ferrero, Low-Frequency Vibrations of Inorganic and Coordination Compound, New York, John Wiley \& Sons (1971).

26. N. Raman, V. Muthuraj, S. Ravichandran and A. Kulandaisamy, Proc. Indian Acad. Sci. (Chem. Sci.), 115, 161 (2003).

27. N. Raman, S. Ravichandran and A. Kulandaisamy, Asian. J. Chem., 14, 1261 (2002).

28. G.B. Deacon, F. Huber and R.J. Phillips, Inorg. Chim. Acta, 41, 104 (1985).

29. T.D. Thangadurai and K. Natarajan, Indian J. Chem., 41, 741 (2002).

30. M. Sonmez and M. Sekerci, Polish J. Chem., 76, 907 (2002).

31. R.S. Downing and F.L. Urbach, J. Am. Chem. Soc., 91, 5977 (1969).

32. B. Bosnich, J. Am. Chem. Soc., 90, 627 (1968).

33. A.B.P. Lever, Inorganic Electronic Spectroscopy, Elsevier, Amsterdam (1984).

34. F.A. Cotton and G. Wilkinson, Advanced Inorganic Chemistry, Academic. Press, New York, edn. 4, p. 790 (1980).

35. N.N. Green and A. Earnshaw, Chemistry of the Elements, Pergamom Press, Oxford, UK, p. 1315 (1984). 